\title{
South-South cohesiveness versus South-South rhetoric: Brazil and Africa at the UN General Assembly
}

\author{
Pedro Seabra $^{1} \cdot$ Edalina Rodrigues Sanches $^{2,3}$
}

(C) Macmillan Publishers Ltd., part of Springer Nature 2018

\begin{abstract}
South-South relations have regained widespread interest in recent years, together with increasingly visible stances on international stages. Brazil's interactions with the African continent, in particular, came to epitomise such a perception while sustaining an expectation of mutual alignment in several global issues. However, these assumptions still lack empirical corroboration. Drawing on United Nations General Assembly voting data for the 1991-2013 timeframe, this article questions a supposed South-South solidarity at the multilateral institution with the largest global representation and identifies key thematic axes that incite greater collective stances. The analysis further sheds light on whether or not a common SouthSouth agenda has emerged over time.
\end{abstract}

Keywords Brazil · Africa $\cdot$ UNGA $\cdot$ Global South

\section{Introduction}

The notion that South-South relations have regained new levels of depth, thus resulting in increasingly visible stances in international stages, has won considerable support in recent years. That, in turn, has been translated into new streams of research

Pedro Seabra

pedro.seabra@iscte-iul.pt

Edalina Rodrigues Sanches

ersanches@ics.ul.pt

1 Centro de Estudos Internacionais, Instituto Universitário de Lisboa (ISCTE-IUL), Av. Forças Armadas, 1649-026 Lisbon, Portugal

2 Instituto de Ciências Sociais, Universidade de Lisboa (ICS-UL), Lisbon, Portugal

3 Instituto Português de Relações Internacionais, Universidade Nova de Lisboa (IPRI-NOVA), Lisbon, Portugal 
that have highlighted venues and topics which substantiate this newfound resurgence (e.g. Braveboy-Wagner 2009; Alden et al. 2010). Overall, these dynamics can be considered a product of two intertwined developments. On the one hand, the noticeable visibility of rising powers from the South, which has led to a subsequent increase in the discourse over common institutionalised positions on a plethora of international issues. On the other hand, the slow decline of the post-Cold War institutional status $q u o$, which has, concomitantly, produced the necessary conditions for an expanded debate that seeks to include dissenting voices in multiple international arenas.

Increased research notwithstanding, it should be noted that wider South-South relations remain since its early days, characterised by diversity, volatility and porosity in their composition, leading to frequent reformulations in alliances and sub-South regional groupings - often due to changes in the political leadership of the main leading countries - in a constant attempt to acquire the greatest possible representation and associated followership. Currently, the 'Global South' can be considered the most neutral definition that encapsulates the 'rough geographical status as well as a general sense of common global problems and aims' (Braveboy-Wagner 2009: 3). More so when considering how 'the widespread use of inverted commons', ranging from the 'West', to the 'developing world', or to the 'Rest', has hindered more consensual analytical categorisations (Hurrell 2013: 215). Meanwhile, other concepts such as South-South Cooperation (SSC) remain strongly embedded in the political-economic dictates of development assistance (e.g. Renzio and Seifert 2014). In every one of these cases, the high-politics component is easily overshadowed as are the intricacies of bilateral contacts and diplomatic practices that allow for cooperation to occur in the first place.

Acknowledging these shortcomings, we opt to follow a broader conceptualisation of South-South relations, in order to better underline the political dimension that we aim to explore here. We are particularly interested in displaying how such dynamics manage to entail or not new diplomatic coalitional realities in world stages (e.g. Rothstein 1977). South-South relations can then be understood as being deeply rooted in a strong sense of common solidarity over global governance, economic and development issues, which provides sufficient basis for the transposition of preliminary discussions into coalitional fronts in international arenas. In other words, we deem them as a mobilising symbol (Alden et al. 2010), manifested through different collective platforms, often against Northern-led conceptualisations of the international order.

South-South relations, however, also constitute a set of extremely fluid interactions, usually dependent on the context at the time of any intended focus. This poses considerable obstacles not only for longitudinal analyses of their inner cohesiveness but also in terms of singling out possible case studies as proper representations of such kind of ties. In our view, Brazilian-African relations may just prove a compromise solution, as a test tube of the intensity behind current South-South relations still in need of factual evaluation. Indeed, after President Luiz Inácio Lula da Silva took office in 2003, South-South relations were formally elevated to new levels of priority. By 'pursuing a psychologically transformative foreign policy agenda in the Global South' (Burges 2005: 1134), Brazil broke with previous conceptualisations and pushed for new political, economic and development relations with alternative partners, including African countries. The latter, for their part, recognised the potential bargaining outcomes in dealing with rising powers and began to privilege more 
'coordinated, collective and coherent engagements' in the external domain (Vickers 2013: 670). Such interactions thus came to epitomise a generalised perception of resurging Southern-led dynamics. One way of promoting and sustaining concerted action and consultations was precisely through the United Nations General Assembly (UNGA), once deemed by Lula da Silva, a 'great forum for general debate concerning humankind's major problems' (Corrêa 2013: 933).

Yet, this state of affairs raises some queries. How far up have perceptions of an expected mutual alignment in the discussion and resolution of several global issues materialised? How cohesive have Brazil and African countries behaved at the UNGA? And how have such relations accompanied the increased relevance attributed to South-South relations in the last few years? By unpacking the gist of South-South relations in the present day, two core goals drive this article: (1) to quantitatively verify a supposed South-South solidarity at the multilateral institution with the largest global representation; and (2) to identify key thematic axes that may or may not incite greater collective stances at the UNGA.

With that in mind, we rely on quantitative data from UNGA voting records between 1991 and 2013 to try and provide a descriptive inference of levels of cohesiveness as well as variations over time and content. We subscribe to the interpretation that such data comprises a valid 'indicator of its foreign policy orientation and international alignments', as well as a 'record of how the state wants to be seen by others, the international norms it finds acceptable, and the positions it is willing to take publicly' (Mattes et al. 2015: 284). More importantly, we focus on possible informal cross-regional groupings at the UNGA, which still remain largely unexplored (Laatikainen 2017). Our option concerning the time period is substantiated by both the need to provide a critical juncture point with significant impact for both Brazil and the African continent - such as the end of the Cold War-and by data restrictions over more recent years. Regardless, the relevance of this research stands out on two separate accounts. On the one hand, the only study of the kind centred on South-South relations within the UNGA dates back to 1988 and exclusively concerns the Group of 77 (G77) (Iida 1988), thus leaving the field lacking a fresh take on the subject. On the other hand, recent studies have either focused on the cohesion of BRICS (Brazil, Russia, India, China and South Africa) (Ferdinand 2014; Hooijmaaijers and Keukeleire 2016), on how such countries perceive their surrounding regions as stepping stones to global projection (Montenegro and Mesquita 2017), or on Brazil-US relations, as a way to historically explain the evolution of the former's foreign policy trajectory (Amorim Neto 2012). No attention has been paid to alternative high-politics formations, such as those heralded by Brazil and Africa in the background of the latest Global South élan. Even less effort has been placed on deconstructing such dynamics as a single unit of analysis. We believe these intertwined gaps further bolster the pertinence of our original standpoint.

The article abides by the ensuing structure. We begin by unpacking the chief expressions of South-South relations at the UNGA over the years. Afterwards, the track record of Brazilian-African relations is dully contextualised. Following some methodological notes, we present the respective data in order to answer the original queries, followed by some concluding remarks highlighting additional niches worthy of further research. 


\section{Translating South-South into the UNGA}

The concept of South-South relations has often stood at the forefront of international politics through the creation of multiple formal and informal coalitions. While sharing a common track record of underdevelopment and previous rule by colonial powers, several Asian, African and Latin American countries sought to devise new alternatives to the post-World War II institutional framework. The Bandung Conference of 1955, in particular, triggered a new wave of collective action as its most evident output, the Non-Aligned Movement (NAM), was founded in 1961 with the core aim of avoiding Third World-involvement in East-West rivalries. Classic realist accounts perceived this as part of a balancing move, in the face of the threat posed by the superpower's military interventionism and economic domination at the time (e.g. Krasner 1985; cf. David 1991). But the NAM's identity was, above all, strongly embedded in 'the evolving notions of non-interference (sovereignty), equality and solidarity between (previously) marginalised/colonised states' (Vieira 2016: 299). Likewise, the G77, founded in 1964 under the purview of the United Nations Conference on Trade and Development (UNCTAD), abided to the same logic and vied for a fairer and more equal international economic order by means of increased concerted action between developing countries.

Unsurprisingly, these dynamics were quickly translated into the UNGA, as the most representative international venue of the time. How to improve their capacity of joint negotiation in the UN system comprised a coveted goal for such groupings, as it provided a 'cost-effective way to have a voice in world affairs' as well as a way to avoid the 'additional expenditure of official visits and resident diplomatic missions' (Braveboy-Wagner 2009: 6). The fact that the regular workload of both the NAM and the G77 was also conducted within the UNGA framework further attested to their shared umbilical connection. In fact, during the Algiers Summit in 1973, the NAM formally established the Coordinating Bureau of the Non-aligned Movement (CoB-NAM) to precisely harmonise UN activities, thus marking its beginning as a "voting bloc within the United Nations and international agencies, subject to growing pressure on its members to conform to non-aligned positions in their voting patterns' (Jackson 1983: 28). Accordingly, common economic and development aims, the struggle for decolonisation, international outcry over Apartheid-led South Africa or the issue of Palestine often provided rallying points to foster common voting positions (Peterson 2006: 13-29; Morphet 1995).

A set of more specific studies on the topic, though, deserve additional reference. Iida (1988), for instance, provided one of the first attempts to grasp the South's inner dynamics by analysing the then-existing solidarity within the G77. ${ }^{1}$ As the interest of such countries in that platform varied, it was possible to conclude that "when Third World states feel that they are losing power, they step up their efforts to coordinate their policy positions so that they will increase their bargaining power. When their power is growing, they have less need for presenting a unified front' (Iida

1 See also Stokman (1977). 
1988: 394). On the other hand, Kim and Russett (1996) argued that, after the Cold War, 'East-West division no longer prevails in General Assembly deliberations; a North-South cleavage has superseded cold war alignments, giving rise to state preferences defined along developmental lines'. In their view, the bipolarity of international relations acted as a buffer that prevented such fault lines from fully emerging but once the context irremediably changed, underlying tensions emerged. Hence, subsequent voting alignment would be expected 'to be shaped by state preferences along developmental lines' while 'views of self-determination and economic development will reflect the continuing great differences between rich and poor nations' (Kim and Russett 1996: 631, 651).

The 1990s, however, spelled significant challenges to such a rational as these countries began to experience different economic track records while also becoming further engrained in the mechanics of an increased globalised world. Previous platforms like UNCTAD lost their centrality as the North-South dividing lines diluted in the face of key developments like the creation of the World Trade Organization (WTO). Moreover, even though both the NAM and the G77 still continued to prove resilient lightning rods (Vieira 2016), it is hard to deny that the weight of these organisations in the wider international context as well as their overall political centrality for Southern countries has become somewhat diluted over time, thus decreasing their usefulness as the sole representative caucuses of South-South relations (Toye 2014). This has been further accentuated by the increased proliferation of other multilateral options and a more fluid set of widespread regional dynamics, which only reinforces the need to explore other tokens of alleged South-South solidarity in the current context.

\section{Brazil, Africa and the Global South in-between}

The historical track record of Brazilian-African relations has not been without its share of obstacles. During the Cold War, Brazil's foreign policy agenda towards the South, in general, and towards Africa, in particular, fluctuated repeatedly while remaining at the mercy of internal political developments. This was due to a structural contradiction in the country's own positioning, in which Brazil presented itself as both 'ahead of Third World countries and out of sync with those in the First World' (Miyamoto 2000: 120; cf. Swain Jr. 1981). The strategy was twofold: on the one hand, the country sought to benefit from its association to then-developing nations in order to reap better advantages in international negotiations; on the other hand, it sought a measured proximity to the superpowers so as to stay close to the main centres of decision (Selcher 1978).

In reflection of these different kinetic forces, Brazil contented itself to an observer status with NAM, as a way to become privy to internal discussions but without fully committing to the political goals that other leading Southern countries advocated at the time. ${ }^{2}$ The G77, however, proved to be a different story, as such a group zeroed in on the New International Economic Order (NIEO) agenda that could eventually

\footnotetext{
${ }^{2}$ For more on Brazil's hesitating stance towards NAM during the 1960s, see Hershberg (2007).
} 
generate direct implications for Brazil's own national development goals. The country's involvement and active participation in multiple UNCTAD meetings and subsequent proceedings at the UNGA were therefore considerably more substantial. In other words, Brazilian leaders proved far more interested in the practical outcomes of the economic agenda pushed by the G77 than in the diffuse political discourse subjacent to the NAM's summitry routine.

Amidst this balance of external priorities, African countries often found themselves caught in-between tenuous spurs of international interest. After a widespread wave of decolonisation, the bulk of the new nations still faced internal battles for power and/or the consolidation of protracted leaderships, which further weakened their external positioning. The power of numbers, i.e. the proliferation of multilateral options between like-minded nations, proved a useful strategy to overcome such a situation, thus also partly justifying their enthusiasm for a South-South solidarity agenda (Cornelissen 2009: 7-10). The end of the Cold War and the following decade, however, brought around a new cycle of international disengagement with Africa.

For its part, and despite continuing interest on African Lusophone countries due to a shared historical and linguistic background, Brazil proved no exception in the overall disconnect with the continent. Renewed overtures across the Atlantic only emerged after 2003. Considered an instrumental component of Brazilian foreign policy agenda during the Lula da Silva years (2003-2010) — and followed, to some extent, by his successor, Dilma Rousseff (2011-2016)—revamped relations with Africa were deemed a part of a larger international insertion agenda, in which South-South alliances would help reduce asymmetries with other developed countries. This strategy involved the promotion of new multilateral forums that strived to accommodate shifting patterns of power. The institutionalisation of the India, Brazil and South Africa (IBSA) Dialogue Forum or the African-South American Summits, for instance, received considerable focus, given its explicit claims to increase Global South representation (e.g. Silva et al. 2016). But the revitalisation of previously dormant formats, like the Zone of Peace and Cooperation in the South Atlantic (ZOPACAS), also followed a similar rationale (Abdenur et al. 2016).

A common thread to these initiatives was the requirement of active participation by African countries as a precondition for both operationalisation and execution of any intended agenda. Consequently, overlapping memberships grew exponentially, which in turn 'weakened rather than bolstered Southern solidarity' (Cornelissen 2009: 24). But amidst the proliferation of multilateral options, Brazil still continued "to position itself as a North-South balancer by trumpeting its "southernness", (Burges 2013: 579) while courting key African votes for its own policy goals. That was particularly evident in the 2003 trade negotiations in Cancun, Mexico, that gave birth to the commercial G-20 or even in the election of Brazilian officials for the WTO and the Food and Agriculture Organization (FAO). But it was also in display at the UN, where Brazil's wider aspirations for a permanent seat at the United Nations Security Council (UNSC) became a clear priority, in tandem with Africa's 
own Ezulwini Consensus on the same topic. ${ }^{3}$ High-politics associations were easily made given that any attempt to achieve an overall UN reform required sufficient arithmetic support at the UNGA. Coalition building with countries from the South was thus perceived as a pre-emptive leverage for any kind of overall UN reform, particularly when considering how African countries have 'historically been able to use this multilateral space to 'reward' their southern partners for supporting the continent's decolonisation and development, and to build political capital for the future' (Vickers 2013: 682).

With this endgame in mind, Brazilian officials used a series of tools to enlist further support. On the one hand, Brazil sought to occupy a symbolical-ideational space in international discussions. That included making good use of its prerogative to formally open UNGA sessions each year and attempt to set the agenda for the coming weeks of high-level intergovernmental contacts. ${ }^{4}$ Speeches by both Lula da Silva and Dilma Rousseff routinely called for greater political centrality of the UNGA as a privileged forum to give voice to marginalised views in the international system (Corrêa 2013). Likewise, the rollout of sectorial initiatives that could further rally additional partners, like the anti-hunger and extreme poverty action presented by Lula da Silva in 2004, showcased the willingness to bring other policy issues to the centre stage. On the other hand, more regular linkages were pursuit in order to translate bilateral affinities into greater multilateral dividends. For instance, 25 mechanisms of political consultations were signed with African countries between 2003 and 2013. ${ }^{5}$ Each and every of these instruments explicitly mentioned the increase of interactions in the UN context as an area susceptible for more contacts and joint activities. Ultimately, this self-reinforcing dynamic built upon a shared perception of the UNGA as a privileged platform for regimenting allied voices in support of common goals to reform international governance structures, including the UN itself.

\section{Hypotheses and methodology}

The previous section elaborated on how Brazilian-African relations intensified in recent years. In this context, we are particularly interested with whether a pattern of vote convergence also emerged at the UNGA. If a growing intersection of agendas and interests took place, we would expect higher levels of voting cohesion between

\footnotetext{
3 Between 1991 and 2013, Brazil held four mandates as a non-permanent member of the UNSC (19931994; 1998-1999; 2004-2005; 2010-2011).

4 This prerogative is based on a long-standing diplomatic tradition, itself believed to have been originated during Brazilian Foreign Minister Oswaldo Aranha's tenure as head of the I special UNGA session in 1947.

5 The mechanisms for political consultations were signed with such countries as Angola (2007), Benin (2007), Cameroon (2010), Cape Verde (2008), Congo (2005), Democratic Republic of Congo (2010), Egypt (2003), Ethiopia (2012), Ghana (2005), Guinea (2011), Guinea-Bissau (2007), Kenya (2005), Liberia (2010), Libya (2009), Mali (2009), Namibia (2008), Niger (2013), Nigeria (2000), Senegal (2002), Sierra Leone (2009), Sudan (2006), Togo (2009), Tunisia (2001), Zambia (2010) and Zimbabwe (2010). Every agreement is available at https://concordia.itamaraty.gov.br/.
} 
Brazil and Africa to take place at the UNGA from a longitudinal perspective. This is to be assumed given the overt efforts led by Brazilian officials to reconnect with Africa while casting such relations under a revamped South-South political mantle. Likewise, African political elites began to be more outspoken on Brazil's support: 'we would approach them, and they would respond. (...) So that makes it very much easy, whether it is at home, whether it is at the UN and any other organisation'. ${ }^{6} \mathrm{We}$ therefore anticipate $\left(H_{1}\right)$ voting cohesion at the UNGA between Brazil and African countries to have significantly increased between 1991 and 2013, and particularly from 2003 onwards. However, in order to not excessively lose country/regional-level variance by taking Africa as a single unit of analysis, we add a further robustness layer to our results by estimating voting cohesion between Brazil and two additional sub-samples. The first comprises 23 countries with whom Brazil signed political consultations agreements during the indicated timeframe. The second consists of a narrower set including only Lusophone African countries, with whom Brazil has maintained more intense bilateral relations over time. ${ }^{7}$ By considering these two samples, we do not take for granted that voting cohesion occurred homogenously; on the contrary, our expectation is to find higher scores within key clusters. In other words, given the formal mechanisms put into place with the former as well as the existing historical, cultural and linguistic connections with the latter, we expect to find $\left(H_{1 a}\right)$ higher levels of voting cohesion between Brazil and 23 selected countries, and even more between Brazil and Lusophone Africa, than with the overall continent.

Still, and as Voeten cautions, this kind of results 'between countries could rise or fall simply because the agenda changes, without any change in state interests. Ignoring this issue in time series applications could lead to biased inferences as these changes in the agenda could be endogenous to outcomes' (2013: 56; see also Kim and Russett 1996). Hence, the content/issue dimension of every resolution needs to be taken into account. Following a previously designed classification (Amorim Neto 2012; see also 'Appendix 1'), we thus aim to uncover whether the South-South rhetoric of renovated Brazilian-African relations followed an overall pattern or evidenced thematic preferences instead. Previous studies of UNGA voting data have demonstrated how Southern countries were fairly united in economic issue areas during the Cold War, but 'miserably divided' on such issues as security and human rights (Iida 1988: 383). After 1991, tentative evidence pointed to the emergence of larger majorities on self-determination and disarmament issues (Kim and Russett 1996: 641). We therefore seek to verify whether those trends hold and argue that $\left(\mathrm{H}_{2}\right)$ voting cohesion at the UNGA between Brazil and African countries between 1991 and 2013 shifted from a prominence of socio-economic issues to a more explicit emphasis on a political-security agenda. Yet again, we expect

\footnotetext{
${ }^{6}$ Interview with Namibian official, Windhoek, 06/05/2014.

7 The first subset includes every African country mentioned on endnote 5, with the exceptions of Ethiopia and Niger. Given that the political consultations agreements with the two countries were signed too close to the timeframe limit (2013), they were not considered to have feasibly produced any effects on the overall voting patterns. The second subset includes Angola, Cape Verde, Guinea-Bissau, Mozambique, and São Tomé and Príncipe.
} 


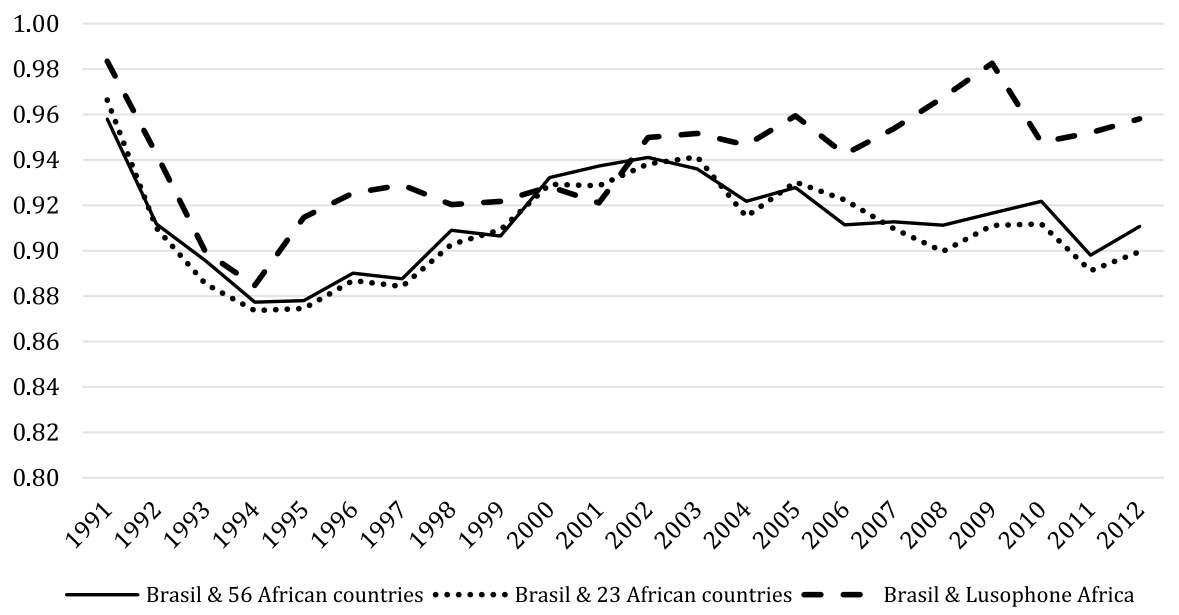

Fig. 1 Agreement Index between Brazil and Africa (1991-2013). Source: United Nations General Assembly Voting Data. Authors' calculations

some variation in results when different clusters of countries are considered. With regard to Lusophone Africa, however, reduction and/or conclusion of civil conflicts together with more pressing needs for reconstruction and economic growth would lead us to anticipate $\left(H_{2 a}\right)$ an inverted shift in reflection of such internal changes, i.e. voting cohesion between Brazil and Lusophone Africa witnessed an adjustment of emphasis from political-security to economic issues.

We draw our analysis from Strezhnev and Voeten's data set (2013), which contains data on every roll-call vote taken at the UNGA between 1946 and 2013, including the individual voting choices of each state member on each resolution. From such vast source material, we extracted a total of 1637 resolutions put to a roll-call vote during the forty-six through the sixty-eightieth sessions (1991 through 2013), involving 55 countries from Africa (54) and Latin America (1). As a measurement formula, we recurred to the Agreement Index (AI), as originally applied by Hix et al. (2005). Perfect cohesion is represented by $A I=1$, whereas $A I=0$ represents no cohesion. ${ }^{8}$

\footnotetext{
${ }^{8}$ The AI treats 'yes', 'no' and 'abstain' on equal footing, thus creating a separate count of each vote choice for each resolution, represented by $Y, N$ and $A$, respectively. AI is given by the following equation:

$$
\mathrm{AI}=\operatorname{MAX}\{Y, N, A\}-0.5[(Y+N+A)-\operatorname{MAX}\{Y, N, A\}] / Y+N+A
$$

Perfect cohesion is represented by $\mathrm{AI}=1$, whereas $\mathrm{AI}=0$ represents no cohesion. If there are equal numbers of 'yes' and 'no' votes, but no 'abstain' votes, then AI $>0$, since countries proved cohesive enough in agreeing not to abstain (Hix et al. 2005: 215). However, we also acknowledge a considerable debate within UNGA literature over different cohesion measures, particular with regard to the issue of abstentions. In that sense, we further tested two alternatives, namely CI and CII, following Hosli et al.'s own designation (2010: 17, 18). Regardless, we found no significant variation between results using CI and $\mathrm{CII}$ and the results obtained while using AI.
} 


\section{Brazil-Africa cohesion at the UNGA}

This section analyses the voting patterns between Brazil and Africa during the 1991-2013 period at the UNGA. The graphical insights shown in Fig. 1 demonstrate that our first hypothesis $\left(H_{1}\right)$ can only be partially confirmed. Indeed, the data systematically depict high AI levels (ranging from 0.87 to 0.98 ) between Brazil and African countries in the period analysed. However, contrary to our initial expectations, cohesion does not increase steadily over time nor does it escalate significantly in the last decade with regard to the two largest samples ('Brazil and 56 African countries' and 'Brazil and 23 African countries'). In fact, three main trends can be instead extracted: (1) downwards in the early 1990s, with AI falling from 0.96 to 0.89 , the lowest value observed in the period; (2) upwards between 1994 and 2002, when AI peaks to 0.94; and (3) overall steadiness from 2003 onwards.

These results can partly result from contextual factors. For instance, lower AI in the first period can be justifiable by the fact this was a period of considerable changes in the African continent. Indeed, during the early 1990s, nearly every state in Sub-Saharan Africa embarked in liberalisation reforms aiming at the realisation of multiparty elections. This period was hallmarked by changes in power (between incumbent and newcomers) and shifting alliances in a post-Cold War global order. It is therefore reasonable to expect a corresponding effect on international engagements. Two other central observations can also be drawn. For one, even though general high levels of cohesion can be observed throughout the last decade, the time span of such pattern differs from what had been originally anticipated. While 1991 proved the apex of overall cohesion, a considerable surge is already visible in 1994/1995 rather than an unequivocal increase from 2003 onwards. More strikingly, the peak of cohesion afterwards can be found in 2002 with a score of 0.94 . This result goes somewhat against the narrative that political reengagement between both sides only started later on. Or, to put it differently, it provides tentative evidence that voting positions at the UNGA were already considerably more in tune than what had been publically perceived or conveyed at the time.

But perhaps even more relevant, it is also visible that cohesion levels with African Lusophone countries fall in line with our initial expectations $\left(\mathrm{H}_{1 a}\right)$ and were indeed noticeably higher. In fact, 2009 witnessed a score of 0.98 , the highest of the three series under analysis. These results point to an understated relational dimension that displays considerably more intensity than wider representation samples, thus providing some credence to a 'cultural rationalisation' that in turn also fuels greater international approximation in multilateral fora.

In order to assess our second hypothesis, we first present a descriptive analysis on the number of resolutions voted per year and per category. As Table 1 shows, there is considerable variation in the primacy given to each category: 'Politics and Security' is by far the most relevant category making up for nearly half of the total resolutions $(N=779 ; 46.6 \%)$. This is followed by 'Social, Technical and Cultural' $(N=387 ; 23.1 \%)$ and 'Colonial/Protectorate' $(N=253 ; 15.1 \%)$, whereas 
Table 1 UNGA resolutions by category per year. Source: United Nations General Assembly Voting Data. Authors' calculations

\begin{tabular}{|c|c|c|c|c|c|c|c|c|c|c|c|c|c|c|}
\hline & \multicolumn{2}{|c|}{$\begin{array}{l}\text { Politics and } \\
\text { Security }\end{array}$} & \multicolumn{2}{|c|}{ Economy } & \multicolumn{2}{|c|}{$\begin{array}{l}\text { Social, Tech- } \\
\text { nical and } \\
\text { Cultural }\end{array}$} & \multicolumn{2}{|c|}{$\begin{array}{l}\text { Colonial/ } \\
\text { Protectorate }\end{array}$} & \multicolumn{2}{|c|}{$\begin{array}{l}\text { UN } \\
\text { Admin- } \\
\text { istration } \\
\text { and } \\
\text { Finance }\end{array}$} & \multicolumn{2}{|c|}{ Legal } & \multicolumn{2}{|l|}{ Total } \\
\hline & $N$ & $\%$ & $N$ & $\%$ & $N$ & $\%$ & $N$ & $\%$ & $N$ & $\%$ & $N$ & $\%$ & $N$ & $\%$ \\
\hline 1991 & 40 & 5.1 & 6 & 6.1 & 16 & 4.1 & 8 & 3.2 & 0 & 0.0 & 4 & 4.8 & 74 & 4.5 \\
\hline 1992 & 42 & 5.4 & 4 & 4.1 & 16 & 4.1 & 8 & 3.2 & 2 & 5.4 & 3 & 3.6 & 75 & 4.6 \\
\hline 1993 & 34 & 4.4 & 4 & 4.1 & 13 & 3.4 & 9 & 3.6 & 1 & 2.7 & 4 & 4.8 & 65 & 4.0 \\
\hline 1994 & 36 & 4.6 & 3 & 3.1 & 13 & 3.4 & 10 & 4.0 & 1 & 2.7 & 5 & 6.0 & 68 & 4.2 \\
\hline 1995 & 35 & 4.5 & 3 & 3.1 & 17 & 4.4 & 22 & 8.7 & 1 & 2.7 & 3 & 3.6 & 81 & 4.9 \\
\hline 1996 & 39 & 5.0 & 4 & 4.1 & 14 & 3.6 & 10 & 4.0 & 3 & 8.1 & 4 & 4.8 & 74 & 4.5 \\
\hline 1997 & 32 & 4.1 & 6 & 6.1 & 18 & 4.7 & 8 & 3.2 & 1 & 2.7 & 5 & 6.0 & 70 & 4.3 \\
\hline 1998 & 34 & 4.4 & 4 & 4.1 & 11 & 2.8 & 8 & 3.2 & 2 & 5.4 & 3 & 3.6 & 62 & 3.8 \\
\hline 1999 & 35 & 4.5 & 4 & 4.1 & 16 & 4.1 & 10 & 4.0 & 1 & 2.7 & 2 & 2.4 & 68 & 4.2 \\
\hline 2000 & 32 & 4.1 & 4 & 4.1 & 16 & 4.1 & 10 & 4.0 & 3 & 8.1 & 3 & 3.6 & 68 & 4.2 \\
\hline 2001 & 32 & 4.1 & 4 & 4.1 & 15 & 3.9 & 10 & 4.0 & 3 & 8.1 & 2 & 2.4 & 66 & 4.0 \\
\hline 2002 & 36 & 4.6 & 4 & 4.1 & 16 & 4.1 & 10 & 4.0 & 1 & 2.7 & 7 & 8.4 & 74 & 4.5 \\
\hline 2003 & 30 & 3.9 & 6 & 6.1 & 22 & 5.7 & 14 & 5.5 & 1 & 2.7 & . & 3.6 & 76 & 4.6 \\
\hline 2004 & 30 & 3.9 & 4 & 4.1 & 18 & 4.7 & 12 & 4.7 & 3 & 8.1 & 5 & 6.0 & 72 & 4.4 \\
\hline 2005 & 31 & 4.0 & 4 & 4.1 & 22 & 5.7 & 11 & 4.3 & 1 & 2.7 & 5 & 6.0 & 74 & 4.5 \\
\hline 2006 & 40 & 5.1 & 3 & 3.1 & 23 & 5.9 & 15 & 5.9 & 3 & 8.1 & 3 & 3.6 & 87 & 5.3 \\
\hline 2007 & 33 & 4.2 & 5 & 5.1 & 23 & 5.9 & 11 & 4.3 & 2 & 5.4 & 3 & 3.6 & 77 & 4.7 \\
\hline 2008 & 33 & 4.2 & 4 & 4.1 & 20 & 5.2 & 12 & 4.7 & 0 & 0.0 & 4 & 4.8 & 73 & 4.5 \\
\hline 2009 & 31 & 4.0 & 6 & 6.1 & 18 & 4.7 & 11 & 4.3 & 1 & 2.7 & 2 & 2.4 & 69 & 4.2 \\
\hline 2010 & 32 & 4.1 & 3 & 3.1 & 14 & 3.6 & 11 & 4.3 & 3 & 8.1 & 4 & 4.8 & 67 & 4.1 \\
\hline 2011 & 31 & 4.0 & 4 & 4.1 & 16 & 4.1 & 10 & 4.0 & 2 & 5.4 & 2 & 2.4 & 65 & 4.0 \\
\hline 2012 & 31 & 4.0 & 5 & 5.1 & 15 & 3.9 & 12 & 4.7 & 1 & 2.7 & 4 & 4.8 & 68 & 4.2 \\
\hline 2013 & 30 & 3.9 & 4 & 4.1 & 15 & 3.9 & 11 & 4.3 & 1 & 2.7 & 3 & 3.6 & 64 & 3.9 \\
\hline Total & 779 & 46.6 & 98 & 5.9 & 387 & 23.1 & 253 & 15.1 & 37 & 2.2 & 83 & 5.0 & 1637 & 97.8 \\
\hline
\end{tabular}

'Economy' $(N=98 ; 5.9 \%)$, 'Legal' $(N=83 ; 5.0 \%)$ and 'UN Administration and Finance' $(N=37 ; 2.2 \%)$ account for considerably less resolutions. Longitudinally there are not clear trends and the average number of resolutions per year is 72 , with the lowest number found in 1998 (62) and the highest in 2006 (87). It is also noteworthy the inexistence of resolutions in 1991 and 2008 concerning 'UN Administration and Finance', hence the exclusion of such years from the graphic representation.

For a finer analysis, Figs. 2, 3, 4, 5, 6 and 7 present the longitudinal evolution of each of the categories considered. It becomes clear how despite generally high cohesion values, there are striking differences across the various categories. Figures 3 and 4 , for instance, put into display how cohesion was overall higher with regard 


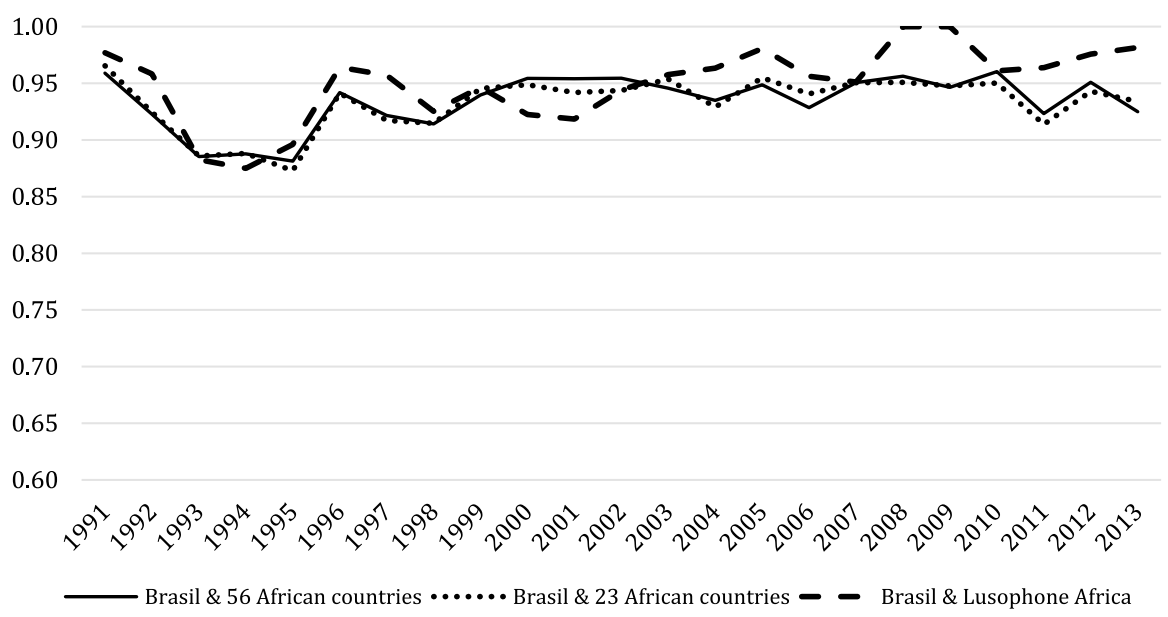

Fig. 2 Agreement Index between Brazil and Africa on 'Politics and Security' issues (1991-2013). Source: United Nations General Assembly Voting Data. Authors' calculations

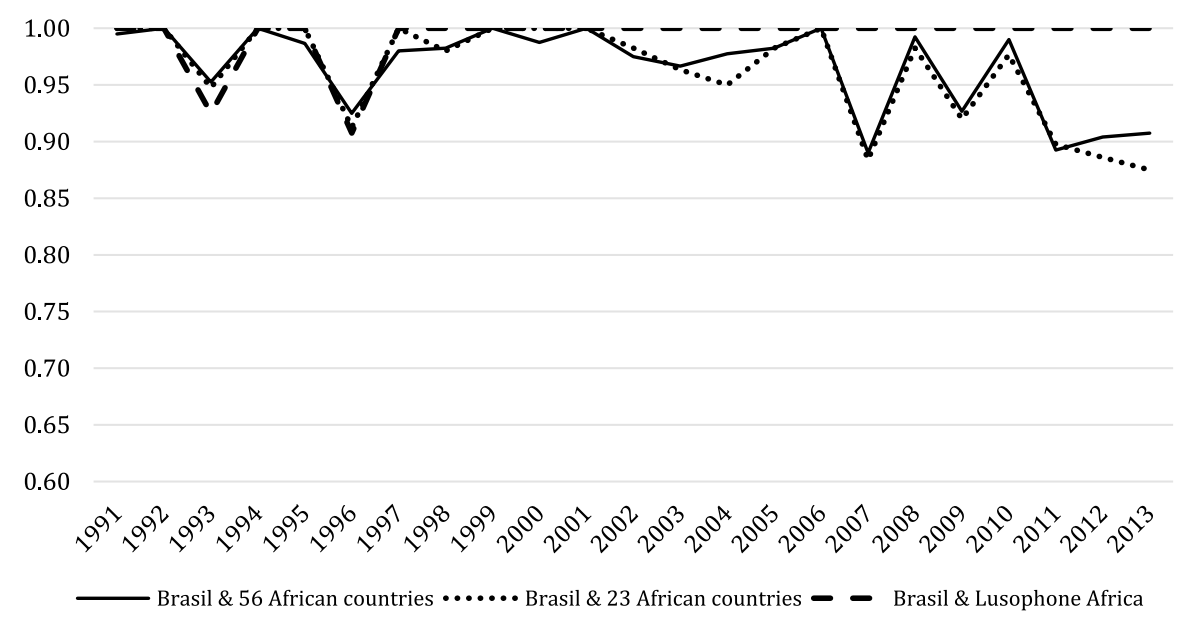

Fig. 3 Agreement Index between Brazil and Africa on 'Economy' issues (1991-2013). Source: United Nations General Assembly Voting Data. Authors' calculations

to resolutions addressing 'Economy' and 'Colonial/Protectorate' issues, while the remaining categories indicate slightly lower results, at some point in time or the other, particularly in terms of 'Social, Technical, and Cultural' issues.

In spite of no uniform temporal trend across all categories, some results do stand out. A few only emerge due to the low number of thematic resolutions assigned in a respective year. For instance, only two resolutions were put to a vote with regard to 'UN Administration and Finance' issues in 2011. But given that one comprised the highly contested resolution 66/1A - concerning credentials for Libyan representatives at the UNGA after the overthrown of Muammar al-Gaddafi-the registered 


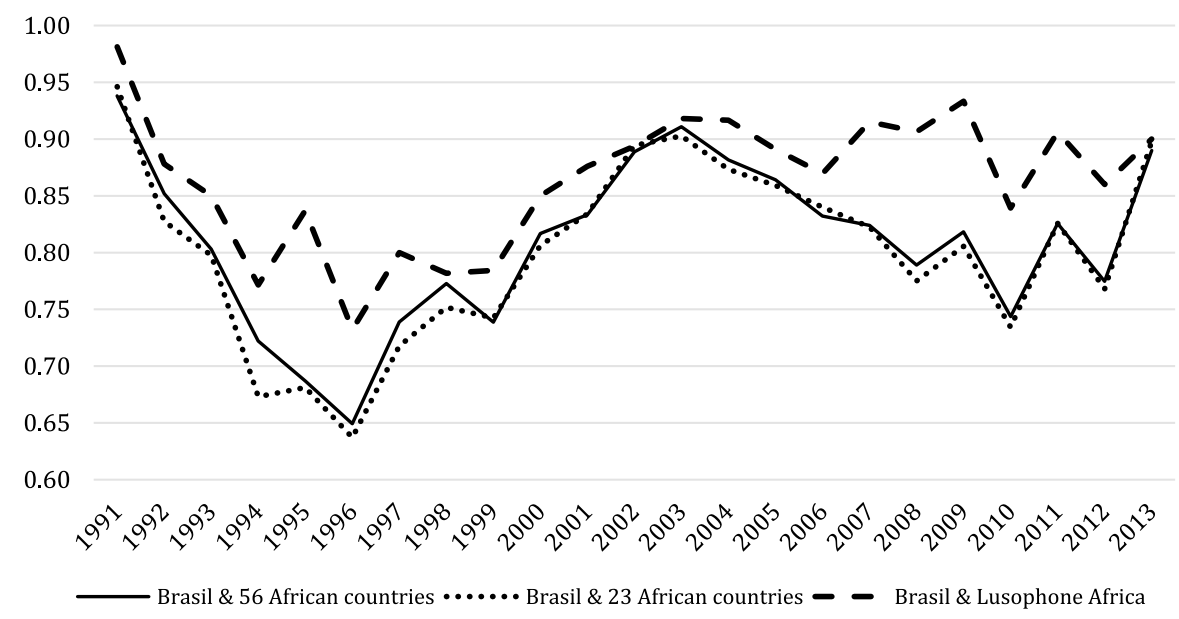

Fig. 4 Agreement Index between Brazil and Africa on 'Social, Technical, and Cultural' issues (19912013). Source: United Nations General Assembly Voting Data. Authors' calculations

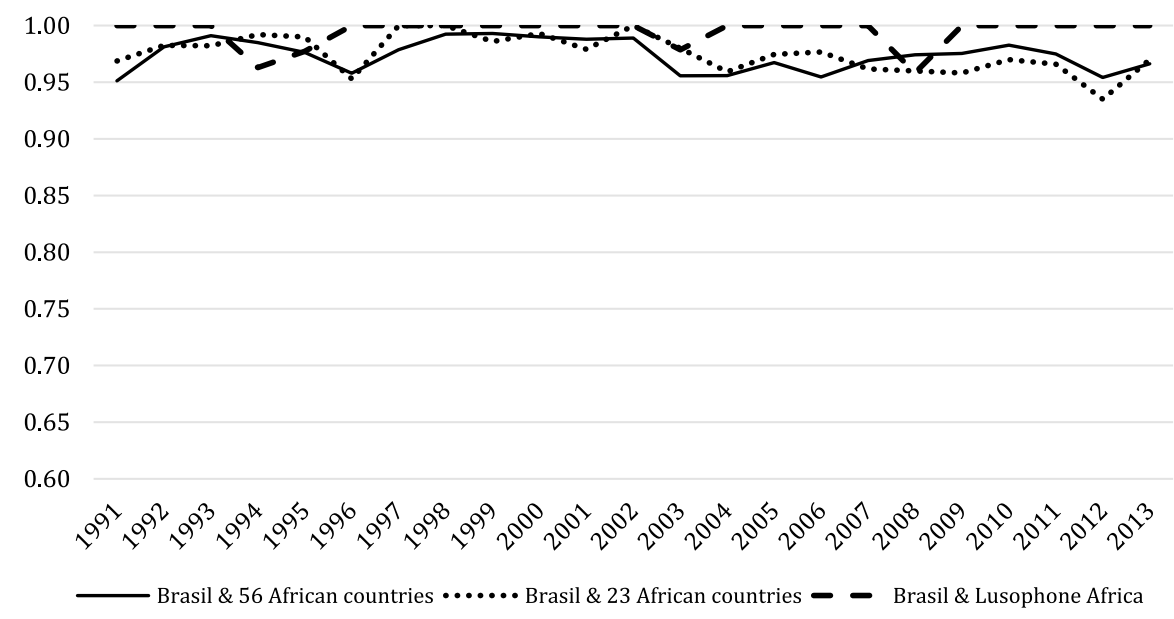

Fig. 5 Agreement Index between Brazil and Africa on 'Colonial/Protectorate' issues (1991-2013). Source: United Nations General Assembly Voting Data. Authors’ calculations

19 votes in favour (Brazil included), 12 votes against and 5 abstentions were sufficient to promote an abrupt decline in AI levels. The same applies to the 'Legal' category in 2004, when Brazil (together with Gabon) voted against the UN Declaration on Human Cloning in resolution 59/280, as opposed to 10 abstentions and 20 votes in favour by African countries. Likewise, regarding 'Economy' issues, the slightly lower levels of agreement observed in 2007 and in 2011 are mainly driven by abstentions in resolutions concerning the use and dissemination of appropriate sustainable agricultural technologies (resolutions 62/190 and 66/195, respectively). 


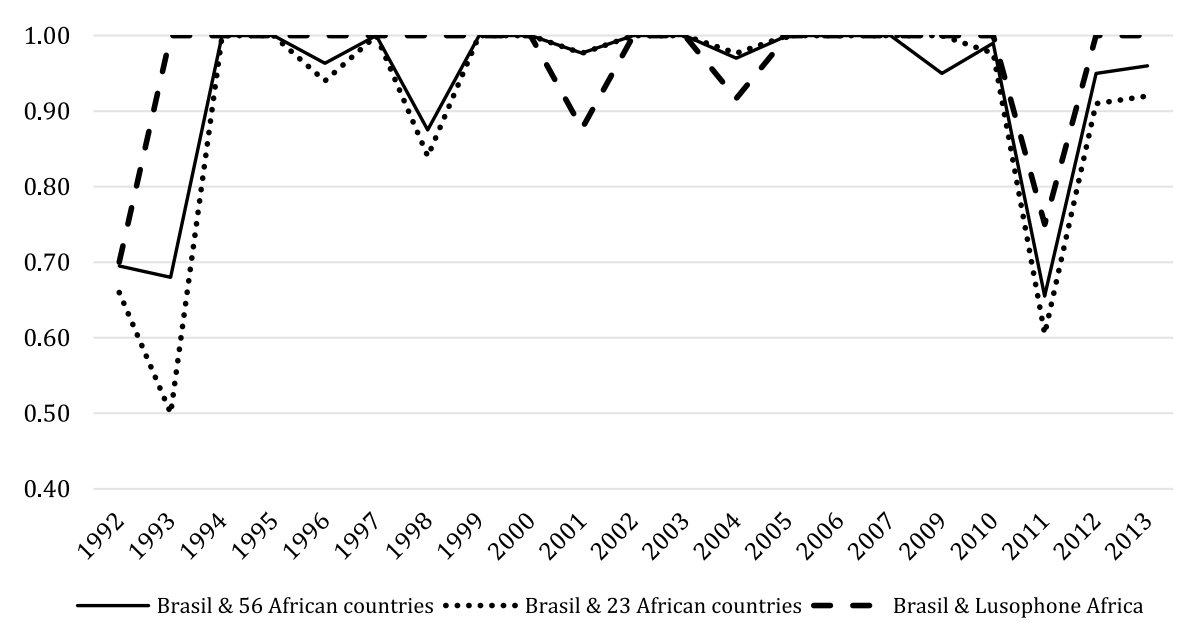

Fig. 6 Agreement Index between Brazil and Africa on 'UN Administration and Finance' issues (19912013). Source: United Nations General Assembly Voting Data. Authors' calculations

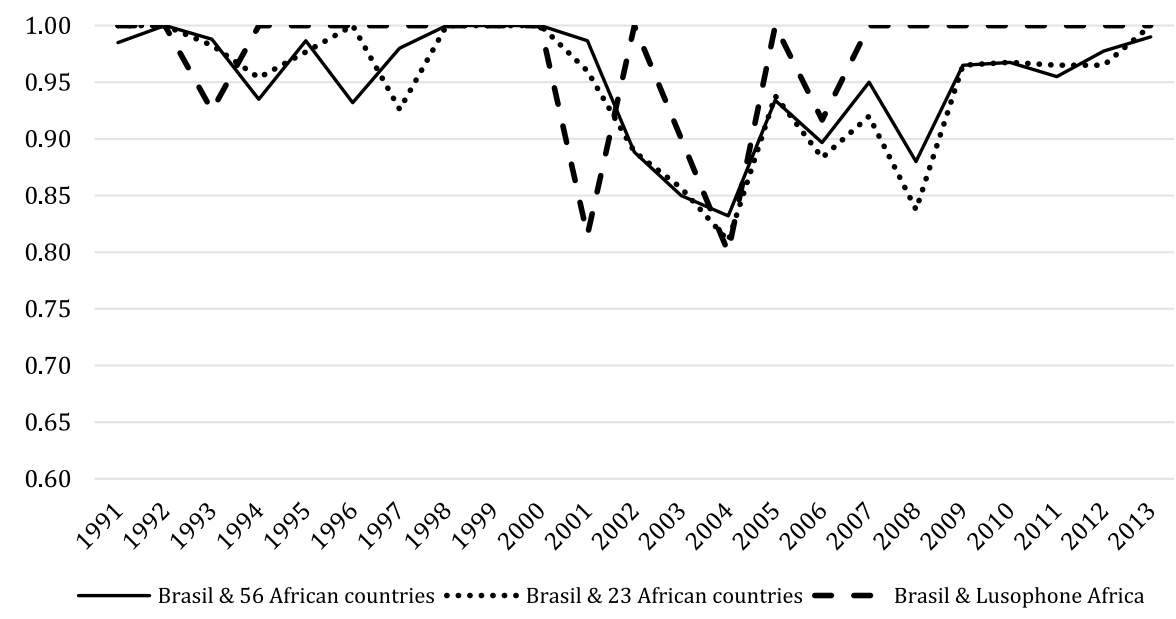

Fig. 7 Agreement Index between Brazil and Africa on 'Legal' issues (1991-2013). Source: United Nations General Assembly Voting Data. Authors' calculations

Other results, however, prove more significant due to the size of the sample in question. 'Social, Technical and Cultural' issues, for example, comprise the second largest category of resolutions, and its inner contention is visible in 1996, when resolution 51/109 on the situation of human rights in Nigeria led to 6 votes in favour (Brazil included), 28 abstentions and 12 votes against. An identical clash within the same issue dimension was recorded in 2008 with regard to resolution 63/168 over a moratorium on death penalty, which enlisted 21 votes in favour (Brazil included), 19 abstentions and 9 votes against. Possible grounds for these variations can be found in 
the imbalances long identified within South-South relations, themselves translatable into a wide 'range of perspectives that reflect, among others factors, local contingencies of ethnicity and faith, differing socio-economic status and resource endowment' (Alden et al. 2010: 223). Or, to put it differently, matters that are put up to a vote and clash with internal affairs, customs and/or traditions, may, in turn, trump possible common South-South stances, whether within the African group itself, or within African countries/clusters and other partners.

Still, based on these findings, our initial expectations are only partially confirmed. While cohesion around 'Politics and Security' issues remained overall high, cohesion around 'Economy' issues continued to hit comparably higher scores, even despite the flotation in recent years. The 'Social, Technical, and Cultural' category, on the other hand, displayed some variation during the period in which South-South relations were supposedly re-brought to the forefront of the international stages. Moreover, the additional sub-samples of African countries proved virtually indistinguishable from the broader continental representation in terms of thematic emphases. Hence, it is neither possible to unequivocally state that the overall pattern followed a transition from economic and development issues to an overt emphasis on post-Cold War high-politics issues nor that the reverse occurred with regard to Lusophone Africa alone. One consisting finding, however, is that cohesion remained yet again generally higher between the latter and Brazil.

\section{Conclusion}

Systemic changes often produce a sizeable impact in international multilateral venues, be that in terms of membership, capabilities or geographic reach. Still, the perception that the UNGA absorbed post-Cold War dynamics and began reflecting newer Southern alignments is not without its critics. Voeten, for instance, once argued that voting at the UNGA in the 1990s was largely one-dimensional, reflecting instead changes in regime type and wealth among the different nations and more closely mirroring the East-West duality during the Cold War rather than a strict North-South one (2000; cf. Malone and Hagman 2002). That said, the UNGA managed to remain at the forefront of South-South debates and is intrinsically connected to its own historical evolution. It therefore remains a useful domain to take the pulse of eventual South-South stimuli.

This article provides three original contributions to the field. Firstly, it adds to studies on the UNGA by exposing how instances of contemporary South-South relations unfold within the current dynamics of such body. By unpacking the content of resolutions, it goes beyond the established notion that such legal instruments only propitiate 'engines of groupthink, given to lowest common denominator outcomes' and calls for greater attention to the work carried out within this specific fold (Heinbecker 2004: 278). Secondly, it presents a novel take on the contemporary role of South-South relations, thus helping to 'put the idea of the Global South back on the political and intellectual map' (Hurrell 2013: 217). And thirdly, it fills a niche over the engagement of rising powers with multilateral forums, and particularly the UNGA, amidst their wider external outreach strategies. 
Overall, three key conclusions can be withdrawn. Firstly, Brazilian-African relations have indeed been met with a considerable level of cohesion at the UNGA, in tandem with a rising public profile in the world stages. However, closer observation also allows us to infer that such an evolution can be in fact traced far back than what it would be expected, thus leading us to question the degree of political capitalisation over such a subject in recent years by each side's respective leaderships. We therefore subscribe to the notion that Brazil-Africa relations at the UNGA-as representative tokens of wider South-South relations-exhibited a sizeable cohesive substance at its core, but one in which both its origin and evolution are less contextdriven than what has been publically perceived until this point. Secondly, assuming informal large political groupings as Brazil and Africa as a single cohesive entity carries the risk of overlooking more specific, and sometimes even more intensive, sub-dynamics of their own. The narrower case of voting positions between Brazil and Lusophone Africa serves as a cautionary tale in that regard. And thirdly, proven general cohesion also does not necessarily equate to a monolithic voting pattern. Rather, thematic differences can be found amidst UNGA records that underscore multiple positions, themselves a likely product of the heterogeneity inherent to the set of countries in question. Likewise, the overall voting pattern has yet to follow expectations that the end of the Cold War would result in significant changes in content within UN proceedings. This may lead us to ultimately question whether the 'artificial division of the world into a global North and global South' remains a simplification, and 'like all simplifications, it overlooks substantial parts of reality' (Weiss 2009: 282).

These conclusions in no way exhaust the topic at bay as we also recognise three other interrelated threads that require further exploring. Firstly, how changes in leadership on both sides impact such results. Recent findings have shown that foreign policy patterns at the UNGA emanating from democratic countries remain fairly consistent and stable over time (Mattes, Leeds and Carroll 2015). On the inverted spectrum, leader turnover in autocratic countries is likelier to lead to more acute shifts in such a venue (Smith 2016). In that sense, Brazil and Africa could both warrant a more in-depth verification of such assumptions. Secondly, we recognise the importance of incorporating voting cohesion into more complex measurement instruments (Drieskens et al. 2014). More attention should be paid to the actual country-sponsors or co-sponsors of the resolutions under analysis in order to effectively break down and measure followership of key nations. And thirdly, it would be worthy to try and replicate these results with regard to other rising powers that have equally made use of the South-South narrative in recent years. The cases of India and China towards Africa, in particular, could hold considerable comparative ramifications for the debate over their own emergence in the world at large.

Ultimately, we did not seek to cast this set of countries as solely Southern in their dealings, nor do their external engagements are exhausted by just such a specific trait. But given how 'Brazil's self-identity [has] sat at the intersection between the West and "the rest", (Spektor 2016: 33; Burges 2013), and how African countries only seem to "'make numbers count" where national interests genuinely align behind a common position' (Brown 2012: 1904), we are required to verify the practical application of hefty declaratory statements. Brazilian-African voting cohesion 
has been historically high, and it will most likely not abate any time soon. This fits the trend of overall South-South cohesion, which has also been significant on its own throughout history. That does not mean, however, it has been met with any particular boost or increase in recent years, as rhetoric would lead us to believe. Discourse is not necessarily empty of content, but it often needs to be translated into practical outcomes. Hence, we would argue there is more than meets the eye in this kind of relations and particularly so, in terms of UNGA voting records. Even though such data cannot and should not be taken at face value, it can still prove a useful barometer of South-South cohesion.

Acknowledgements Previous versions of this paper were presented at the 2015 General Conference of the International Studies Association in New Orleans and at the 2017 International Studies AssociationAsia Conference in Hong Kong. We thank the feedback obtained at such occasions as well as Sandra Destradi, Medha, Rafael Mesquita and Octávio Amorim Neto for useful comments and suggestions on subsequent versions. We particularly thank the latter for granting us access to a previous data set. Full responsibility over the final content of the article, however, remains with the authors alone.

Funding This work was supported by the Foundation for Science and Technology (FCT) under Grants SFRH/BPD/103318/2014 and SFRH/BPD/116700/2016.

\section{Appendix 1}

See Table 2. 
Table 2 Thematic classification of resolutions. Reproduced with permission form Amorim Neto (2012)

\begin{tabular}{|c|c|}
\hline Main categories & Sub-categories \\
\hline 1. Politics and Security & $\begin{array}{l}\text { Disarmament and arms (general) } \\
\text { Nuclear weapons } \\
\text { Territorial integrity-sovereignty } \\
\text { Internal affairs/civil rights } \\
\text { Peace operations } \\
\text { Politics and security (others) } \\
\text { Israel-Palestine }\end{array}$ \\
\hline 2. Economy & $\begin{array}{l}\text { Industrial and economic development } \\
\text { Food and agriculture } \\
\text { Aid } \\
\text { Trade } \\
\text { Natural resources }\end{array}$ \\
\hline 3. Social, Technical and Cultural & $\begin{array}{l}\text { Social-cultural } \\
\text { Scientific-technological } \\
\text { Health } \\
\text { Humanitarian/refugees/human rights } \\
\text { Education } \\
\text { Population } \\
\text { Environment } \\
\text { Others }\end{array}$ \\
\hline 4. Colonial/Protectorate & Reforms, independence, self-determination \\
\hline 5. UN Administration and Finance & $\begin{array}{l}\text { Budget } \\
\text { Administration } \\
\text { Members' admission } \\
\text { Procedures } \\
\text { Representation }\end{array}$ \\
\hline 6. Legal & $\begin{array}{l}\text { International Court of Justice } \\
\text { Treaties, legal instruments } \\
\text { Inquiries, reports }\end{array}$ \\
\hline
\end{tabular}

\section{References}

Abdenur, A.E., F. Mattheis, and P. Seabra. 2016. An ocean for the Global South: Brazil and the zone of peace and cooperation in the South Atlantic. Cambridge Review of International Affairs 29(3): $1112-1131$.

Alden, C., S. Morphet, and M. Vieira. 2010. The South in world politics. Basingstoke: Palgrave Macmillan.

Amorim Neto, O. 2012. De Dutra a Lula: A condução e os determinantes da política externa brasileira. Rio de Janeiro: Editora Campos.

Braveboy-Wagner, J. 2009. Institutions of the Global South. London: Routledge.

Brown, W. 2012. A question of agency: Africa in international politics. Third World Quarterly 33(10): 1889-1908. 
Burges, S. 2005. Auto-Estima in Brazil: The logic of Lula's South-South Foreign Policy. International Journal 60(4): 1133-1151.

Burges, S. 2013. Brazil as a bridge between old and new powers? International Affairs 89(3): 577-594.

Cornelissen, S. 2009. Awkward Embraces: Emerging and Established Powers and the Shifting Fortunes of Africa's International Relations in the Twenty-First Century. Politikon: South African Journal of Political Studies 36(1): 5-26.

Corrêa, L.F.S. 2013. Brazil in the United Nations 1946-2011. Brasília: Fundação Alexandre de Gusmão.

David, S.R. 1991. Explaining Third World Alignment. World Politics 43(2): 233-256.

Drieskens, E., R. Van Genderen, and Y. Reykers. 2014. From indications to indicators: Measuring regional leadership in the UN context. Journal of Policy Modeling 36(1): 151-171.

Ferdinand, P. 2014. Rising powers at the UN: An analysis of the voting behaviour of BRICS in the General Assembly. Third World Quarterly 35(3): 376-391.

Heinbecker, P. 2004. Washington's Exceptionalism and the United Nations. Global Governance: A Review of Multilateralism and International Organizations 10(3): 273-279.

Hershberg, J.G. 2007. 'High-Spirited Confusion': Brazil, the 1961 Belgrade Non-Aligned Conference, and the Limits of an 'Independent' Foreign Policy during the High Cold War. Cold War History 7(3): 373-388.

Hix, S., A. Noury, and G. Roland. 2005. Power to the Parties: Cohesion and Competition in the EU Parliament, 1979-2001. British Journal of Political Science 35(2): 209-234.

Hooijmaaijers, B., and S. Keukeleire. 2016. Voting Cohesion of the BRICS Countries in the UN General Assembly, 2006-2014: A BRICS Too Far? Global Governance: A Review of Multilateralism and International Organizations 22(3): 389-407.

Hosli, M.O., van Kampen, E., Meijerink, F., and Tennis, K. 2010. Voting cohesion in the United Nations General Assembly: The case of the European Union. Paper presented at the ECPR Fifth Pan-European Conference; June 24-26, Porto, Portugal.

Hurrell, A. 2013. Narratives of emergence: Rising powers and the end of the Third World? Brazilian Journal of Political Economy 33(2): 203-221.

Iida, K. 1988. Third World Solidarity: The Group of 77 in the UN General Assembly. International Organization 42(2): 375-395.

Jackson, R. 1983. The Non-Aligned, the UN and the Superpowers. New York: Praeger.

Kim, S.Y., and B. Russett. 1996. The New Politics of Voting Alignments in the United Nations General Assembly. International Organization 50(4): 629-652.

Krasner, S. 1985. Structural Conflict: The Third World against Global Liberalism. Berkeley: University of California Press.

Laatikainen, K.V. 2017. Conceptualizing Groups in UN Multilateralism: The Diplomatic Practice of Group Politics. The Hague Journal of Diplomacy 12(2-3): 113-137.

Malone, D.M., and L. Hagman. 2002. The North-South Divide at the United Nations: Fading at Last? Security Dialogue 33(4): 319-414.

Mattes, M., B.A. Leeds, and R. Carroll. 2015. Leadership Turnover and Foreign Policy Change: Societal Interests, Domestic Institutions, and Voting in the United Nations. International Studies Quarterly 59(2): 280-290.

Miyamoto, S. 2000. O Brasil e as Negociações Multilaterais. Revista Brasileira de Política Internacional 43(1): 119-137.

Montenegro, R.H., and R. Mesquita. 2017. Leaders or Loners? How Do the BRICS Countries and their Regions Vote in the UN General Assembly. Brazilian Political Science Review 11(2): 1-32.

Morphet, S. 1995. The influence of states and groups of states on and in the Security Council and General Assembly, 1980-94. Review of International Studies 21(4): 435-462.

Peterson, M.J. 2006. The UN General Assembly. London and New York: Routledge.

Renzio, P., and J. Seifert. 2014. South-South cooperation and the future of development assistance: Mapping actors and options. Third World Quarterly 35(10): 1860-1875.

Rothstein, R.L. 1977. The Weak in the World of the Strong. The Developing Countries in the International System. New York: Columbia University Press.

Selcher, W. 1978. Brazil's Multilateral Relations: Between First and Third Worlds. Boulder: Westview Press.

Silva, A.L.R., A.P. Spohr, and I.L. Silveira. 2016. From Bandung to Brasilia: IBSA and the political lineage of South-South cooperation. South African Journal of International Affairs 23(2): 167-184.

Smith, A. 2016. Leader Turnover, Institutions, and Voting at the UN General Assembly. Journal of Conflict Resolution 60(1): 143-163. 
Spektor, M. 2016. Brazil: Shadows of the Past and Contested Ambitions. In Shaper nations: Strategies for a changing world, ed. W.I. Hitchcock, M.P. Leffler, and J.W. Legro, 17-35. Cambridge, Massachusetts: Harvard University Press.

Stokman, F.N. 1977. Roll Calls and Sponsorship: A Methodological Analysis of Third World Group Formation in the United Nations. Leiden: Sijthoff.

Strezhnev, A., and Voeten, E. 2013. United Nations General Assembly Voting Data (7.0). http://hdl.handl e.net/1902.1/123792. Accessed 10 Jan 2015.

Swain Jr., J. 1981. Normative foreign policy: The Brazilian case. International Interactions 8(1-2): 79-92.

Toye, J. 2014. Assessing the G77: 50 years after UNCTAD and 40 years after the NIEO. Third World Quarterly 35(10): 1759-1774.

Vickers, B. 2013. Africa and the rising powers: Bargaining for the 'marginalized many'. International Affairs 89(3): 673-693.

Vieira, M. 2016. Understanding Resilience in International Relations: The Non-Aligned Movement and Ontological Security. International Studies Review 18(2): 290-311.

Voeten, E. 2000. Clashes in the Assembly. International Organization 54(2): 185-215.

Voeten, E. 2013. Data and analyses of voting in the United Nations General Assembly. In Routledge Handbook of International Organization, ed. B. Reinalda, 54-66. Abingdon: Routledge.

Weiss, T.G. 2009. Moving Beyond North-South Theatre. Third World Quarterly 30(2): 271-284. 